\title{
Bantu Language
}

National Cancer Institute

\section{Source}

National Cancer Institute. Bantu Language. NCI Thesaurus. Code C161853.

A large family of languages spoken by the Bantu peoples throughout Sub-Saharan Africa. 